\title{
Attitudes of Filipino Youth Customers Toward Online Shopping
}

\author{
Kim Edward S. Santos, MBA
}

Wesleyan University Philippines, Philippines

\begin{abstract}
Among the numerous platforms for business and trade, online shopping is a new and emerging platform that provides consumers with convenience. The purpose of this study was to examine how Filipino youth customers use online shopping in terms of factors such as convenience, web design/features, time savings, and security. The descriptive method was used in this study The study surveyed a total of 67 respondents aged 16 to 19, all of whom were students at Wesleyan University-Philippines. The researcher concluded that the use of online shopping (1) saves time when purchasing products / services; (2) is easy and convenient by choosing and making comparison with other products; (3) provides all relevant and accurate information about their products / services; and (4) gives opportunity to check that their transaction online will not cause any problem by considering legitimate online sellers. It was then recommended that (1) in order to improve the aspects that influence consumers, it is vital to understand their experience with online shopping; (2) consumers must always check the authenticity of online shopping page, its product and services; and (3) further research must be included in terms of buying behavior of customer towards online shopping.
\end{abstract}

Keywords-Online Shopping, Convenience, Time Saving, Web Design, Security.

\section{INTRODUCTION}

Among the numerous platforms for business and trade, online shopping is a new and emerging platform that provides consumers with convenience. Online shopping is described as a process through which a client makes an online purchase of a service or product (Jusoh \& Ling, 2012). This enables customers to save money, effort, and time while making online purchases (Al-Debei et al., 2015). As a result, customers are more concerned with the internet vendor's marketing strategy and reputation (Jun \& Jaafar, 2011)
In terms of web design, online sellers must offer competitive prices for their items in order to attract online customers to their websites and persuade them to make a purchase choice (Delafrooz et al., 2009). Further, online website design should induce a sense of social engagement on a business website with text and images may be an immediate and feasible aim for online sellers (Hassanein \& Head, 2007). Evidently, the higher the quality of an online business' website, the more favorable consumers' perceptions of that business are (Zhou, 2011).

In terms of security, the relationship between vendor trust and attitude toward online shopping becomes more significant as people's privacy and security issues increase (McCole et al., 2010). Further, consumer attitudes about online shopping appear to be positively influenced by perceived security and product engagement (Keisidou et al., 2011). Thus, If online merchants do not upgrade their security systems to increase customers' safety knowledge, it will harm consumers' willingness to shop online (Tsai \& Yeh, 2010). With the advancement of technology and the emergence of creative platforms, it is critical to assess consumers' attitudes regarding online buying.

\section{OBJECTIVES OF THE STUDY}

The purpose of this study was to examine how Filipino youth customers use online shopping in terms of factors such as convenience, web design/features, time savings, and security.

\section{METHODOLOGY}

The descriptive method was used in this study to ascertain the underlying causes or emerging trends (Cohen et al., 2002). The study surveyed a total of 67 respondents aged 16 to 19 , all of whom were students at Wesleyan UniversityPhilippines. The questionnaire used in this study was adopted from the study of Gotland (2011). 


\section{RESULTS AND DISCUSSIONS}

Table 1. Convenience

\begin{tabular}{|llll|}
\hline & \multicolumn{1}{c}{ Statement } & \multicolumn{1}{c|}{$\begin{array}{c}\text { Verbal } \\
\text { Interpretation }\end{array}$} \\
1. I get products on time delivery by shopping online & 4.18 & Often \\
2. Detail information is available while shopping online & 3.84 & Often \\
3. I can buy the products anytime 24 hours a day while shopping online & 4.24 & Always \\
4. It is easy to choose and make comparison with other products while shopping & 4.17 & Often \\
& online & General Weighted Mean & $\mathbf{4 . 1 1}$ \\
\end{tabular}

$\begin{array}{ll}\text { Legend } & \text { Verbal Interpretation (VI) } \\ 4.20-5.00 & \text { Always } \\ 3.40-4.19 & \text { Often } \\ 2.60-3.39 & \text { Sometimes } \\ 1.80-2.59 & \text { Rarely } \\ 1.00-1.79 & \text { Never }\end{array}$

Table 1 shows how convenient online shopping is for the Filipino youth customers. Filipino youth scored a general weighted mean of 4.11, which has verbal interpretation of "Often" in terms of convenience. The always experienced Statement 3 "I can buy the products anytime 24 hours a day while shopping online" (Mean $=4.24)$. This result implies that they can purchase products and services online easily and conveniently. They can place orders in a relatively short period without having to leave their homes or offices, making the procedure incredibly quick.
As a result of customers' preference for convenience, businesses have extended one-stop shopping, altered store operating systems, and prioritized service sales, according to Seiders, Berry, and Gresham (2000). They also promote a number of strategies for making shopping more convenient for customers, including improving the speed and ease with which customers may locate a business, identify, select, and obtain products, and change transactions.

Table 2. Web Design/Feature

\begin{tabular}{|c|c|c|}
\hline & \multirow{2}{*}{$\begin{array}{c}\text { Verbal } \\
\text { Interpretation }\end{array}$} \\
\hline Statement & Mean & \\
\hline 1. The website design helps me in searching the products easily & 3.93 & Often \\
\hline $\begin{array}{l}\text { 2. While shopping online, I prefer to purchase from a website that provides safety and } \\
\text { ease of navigation and order }\end{array}$ & 3.92 & Often \\
\hline $\begin{array}{l}\text { 3. The website layout helps me in searching and selecting the right product while } \\
\text { shopping online }\end{array}$ & 4.18 & Often \\
\hline $\begin{array}{l}\text { 4. I believe that familiarity with the website before making actual purchase reduce the } \\
\text { risk of shopping online }\end{array}$ & 4.39 & Always \\
\hline 5. I prefer to buy from website that provides me with quality of information & 3.92 & Often \\
\hline General Weighted Mean & 4.07 & Often \\
\hline
\end{tabular}

$\begin{array}{ll}\text { Legend } & \text { Verbal Interpretation (VI) } \\ 4.20-5.00 & \text { Always } \\ 3.40-4.19 & \text { Often } \\ 2.60-3.39 & \text { Sometimes } \\ 1.80-2.59 & \text { Rarely } \\ 1.00-1.79 & \text { Never }\end{array}$

Table 2 presents how Filipino youth customers evaluate the use of online shopping in terms of its web design / feature. Filipino youth scored a general weighted mean of 4.07 that has verbal interpretation of "Often" based on the web design / feature. They always experienced Statement 4 "I believe that familiarity with the website before making actual 
purchase reduce the risk of shopping online" (Mean $=4.39)$. The result affirms Smith (2007) and Lin, Wu, and Chang (2007) that customers expect internet retailers to provide all relevant and accurate information about their products.
Online retailers must transmit this information because online shoppers rarely have the option to touch and feel items before making a purchase decision.

Table 3 Time Saving

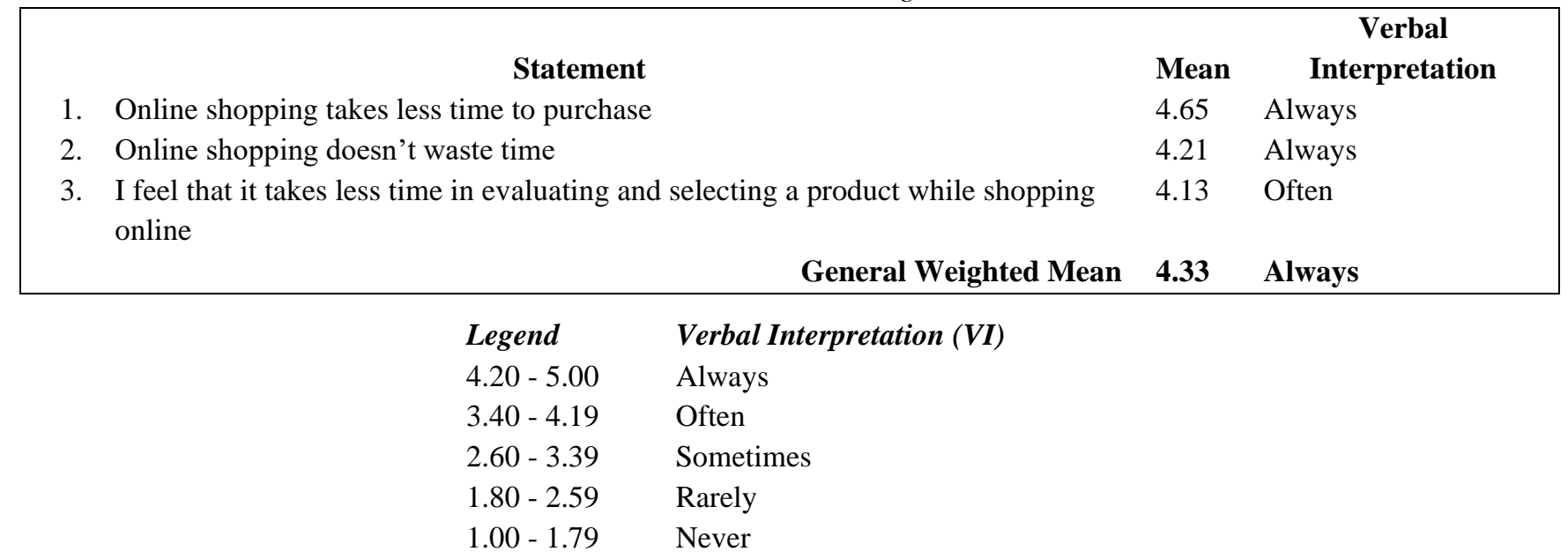

Table 3 presents how Filipino youth customers save time when shopping online. Filipino youth scored a general weighted mean of 4.33 that has verbal interpretation of "Always" in time saving. They always experience Statement 1 "Online shopping takes less time to purchase." (Mean = 4.65) and Statement 2 "Online shopping doesn't waste time." (Mean $=4.21$ ). These results imply that when shopping online Filipino youth were able to spend their time wisely. The internet's most useful characteristic is that it saves time, making it suitable for people that do not have time to shop on a daily basis on the high street. Rather than spending hours going through multiple shops, you can buy products in a few clicks online. This confirms Alreck and Settle's (2002) claim that interactive shopping eliminates the need for the consumer to drive to and from a store or to shop in one or more places, allowing them to focus solely on receiving information and making a purchase decision.

Table 4. Security

\begin{tabular}{|c|c|c|c|c|}
\hline \multicolumn{3}{|c|}{ Statement } & \multirow{2}{*}{$\begin{array}{l}\text { Mean } \\
2.76\end{array}$} & \multirow{2}{*}{$\begin{array}{l}\text { Verbal Interpretation } \\
\text { Sometimes }\end{array}$} \\
\hline 1. & I feel safe and secure w & shopping online & & \\
\hline 2. & Online Shopping protec & y security & 2.88 & Sometimes \\
\hline \multirow{2}{*}{\multicolumn{3}{|c|}{ General Weighted Mean }} & 3.41 & Often \\
\hline & & & 3.02 & Sometimes \\
\hline & Legend & Verbal Interpretati & $n(V I)$ & \\
\hline & $4.20-5.00$ & Always & & \\
\hline & $3.40-4.19$ & Often & & \\
\hline & $2.60-3.39$ & Sometimes & & \\
\hline & $1.80-2.59$ & Rarely & & \\
\hline & $1.00-1.79$ & Never & & \\
\hline
\end{tabular}

Table 4 illustrates how secure online shopping is for the Filipino youth customers. Filipino youth scored a general weighted mean of 3.02, which has a verbal interpretation of "Sometimes". They sometimes felt safety $($ Mean $=2.76)$ and secured (Mean $=2.88$ ) while shopping online. However, they often experienced Statement 3 "I like to shop online from a trustworthy website." The results imply that Filipino youth customers check that their transaction online will not cause any problem by considering legitimate online sellers. Trust is considered as a separate but potentially coexisting strategy for reducing the unpredictability and complexity of electronic market transactions and connections from a functional standpoint Grabner-Kraeuter (2002). 
Table 5. Comparative Mean of Four Factors

\begin{tabular}{|lcc|}
\hline \multicolumn{1}{|r}{ Factor } & $\begin{array}{c}\text { General Weighted } \\
\text { Mean }\end{array}$ & Rank \\
Convenience & 4.11 & 2 \\
Web & & \\
design/feature & 4.07 & 3 \\
Time Saving & 4.33 & 1 \\
Security & 3.02 & 4 \\
\hline
\end{tabular}

The comparative mean of four factors affecting how Filipino youth customers use online shopping is shown in Table 5. Based on the result, Filipino youth use online shopping for time saving $($ Mean $=4.33)$, convenience $($ Mean $=4.11)$, web design / feature $($ Mean $=4.07)$, and security $($ Mean = 3.02), respectively.

\section{CONCLUSIONS AND RECOMMENDATIONS}

This research focused on examining the use of online shopping among Filipino youth customers. The researcher concluded that the use of online shopping (1) saves time when purchasing products / services; (2) is easy and convenient by choosing and making comparison with other products; (3) provides all relevant and accurate information about their products / services; and (4) gives opportunity to check that their transaction online will not cause any problem by considering legitimate online sellers.

It was then recommended that (1) in order to improve the aspects that influence consumers, it is vital to understand their experience with online shopping; (2) consumers must always check the authenticity of online shopping page, its product and services; and (3) further research must be included in terms of buying behavior of customer towards online shopping.

\section{REFERENCES}

[1] Al-Debei, M. M., Akroush, M. N., \& Ashouri, M. I. (2015). Consumer attitudes towards online shopping: the effects of trust, perceived benefits, and perceived web quality. Internet Research.

[2] Alreck, P. L., \& Settle, R. B. (2002). The hurried consumer: Time-saving perceptions of Internet and catalogue shopping. Journal of Database Marketing \& Customer Strategy Management, 10(1), 25-35.

[3] Cohen, L., Manion, L., \& Morrison, K. (2002). Research methods in education. routledge.

[4] Delafrooz, N., Paim, L. H., Haron, S. A., Sidin, S. M., \& Khatibi, A. (2009). Factors affecting students attitude toward online shopping. African Journal of Business Management, 3(5), 200-209.

[5] Grabner-Kraeuter, S. (2002). The role of consumers' trust in online-shopping. Journal of business ethics, 39(1), 43-50

[6] Hassanein, K., \& Head, M. (2007). Manipulating perceived social presence through the web interface and its impact on attitude towards online shopping. International journal of human-computer studies, 65(8), 689-708.

[7] Jun, G., \& Jaafar, N. I. (2011). A study on consumers' attitude towards online shopping in China. International Journal of Business and Social Science, 2(22), 122-132.

[8] Jusoh, Z. M., \& Ling, G. H. (2012). Factors influencing consumers' attitude towards e-commerce purchases through online shopping. International Journal of Humanities and Social Science, 2(4), 223-230.

[9] Keisidou, E., Sarigiannidis, L., \& Maditinos, D. (2011). Consumer characteristics and their effect on accepting online shopping, in the context of different product types. International Journal of Business Science \& Applied Management (IJBSAM), 6(2), 31-51.

[10] McCole, P., Ramsey, E., \& Williams, J. (2010). Trust considerations on attitudes towards online purchasing: The moderating effect of privacy and security concerns. Journal of Business Research, 63(9-10), 1018-1024.

[11] Lin, C. C., Wu, H. Y., \& Chang, Y. F. (2011). The critical factors impact on online customer satisfaction. Procedia Computer Science, 3, 276-281.

[12] pa Gotland, H. (2011). Consumers' Attitude towards Online Shopping Factors influencing Gotland consumers to shop online (Doctoral dissertation, Master Thesis in Business Administration, Department of Business Administration, $\mathrm{Pa}$ Gotland).

[13] Seiders, K., Berry, L.L. and Gresham, L. (2000), "Attention retailers: how convenient is your convenience strategy?", Sloan Management Review, Vol. 49 No. 3, pp. 79-90.

[14] Smith, A. D. (2007). Collaborative commerce through webbased information integration technologies. International journal of innovation and learning, 4(2), 127-144.

[15] Zhou, T. (2011). Examining the critical success factors of mobile website adoption. Online information review. 